\title{
Pelecehan Seksual di Tempat Kerja dengan Self-esteem pada Karyawati Minangkabau di Sumatera Barat
}

\author{
Mizda Atira $^{1}$ Rida Yanna Primanita ${ }^{2}$ \\ 1,2Jurusan Psikologi, Fakultas Ilmu pendidikan, Universitas Negeri Padang \\ e-mail: azimizda@gmail.com
}

\begin{abstract}
The purpose of this study is to investigate the correlation of sexual harassment against self-esteem among female employees from Minangkabau ethnic at the workplace in West Sumatera. A total of 30 respondents from various type of job as respondents. Sexual Experiences Questionnaire (SEQ) and self-esteem scale are employed as measurement tools to measure the sexual harassment and self-esteem. Correlations analysis is utilized to analyze the collected data. The main findings revealed that sexual harassments have a negative significant and relationship with and self-esteem. In addition it is also found that the respondents are in low level of sexual harassment and most respondents are in high level of self-esteem.
\end{abstract}

Keywords: Sexual harassment, self-esteem, female employees, Minangkabau, Sumatera Barat

\begin{abstract}
Abstrak: Budaya Minangkabau yang menganut system matrilineal tentu menanamkan berbagai nila-nilai tersendiri mengenai perempuan. Namun angka pelecehan seksual di Sumatera Barat tergolong tinggi. Penelitian ini bertujuan untuk melihat hubungan antara pelecehan seksual di tempat kerja dengan self-esteem pada karyawati Minangkabau di Sumatera Barat. Subjek terdiri dari 30 karyawati yang berasal dari berbagai jenis pekerjaan. Pengumpulan data menggunakan skala pelecehan seksual Sexual Experiences Questionnaire (SEQ) dan skala self-esteem. Untuk teknik analisis data menggunakan teknik uji korelasi Product Moment. Hasil penelitian menunjukkan bahwa tidak terdapat hubungan yang signifikan antara pelecehan seksual terhadap self-esteem subjek. Selain itu data penelitian menunjukkan bahwa pelecehan seksual yang dialami subjek berada pada kategori rendah sedangkan self-esteem mereka berada pada kaegori tinggi.
\end{abstract}

Kata kunci: Pelecehan seksual, self-esteem, karyawati, Minangkabau, Sumatera Barat.

\section{Pendahuluan}

Perkembangan zaman menyebabkan fenomena perempuan yang bekerja menjadi hal yang biasa. Perempuan bahkan diperbolehkan untuk menduduki posisi yang penting dalam berbagai bidang kehidupan seperti Manajer, Menteri bahkan Presiden (Handayani, 2013). Namun, perempuan yang bekerja rentan mengalami ketidakadilan dalam pekerjaannya. Salah satu yang mereka alami yaitu seksisme. Seksisme adalah diskriminasi yang diberikan terhadap seorang individu berdasarkan jenis kelaminnya (Helgeson, 2012).

Prinsip seksisme tidak berlaku di Indonesia. Indonesia dengan berbagai keanekaragaman suku dan budayanya memilki aturan dan norma tersendiri mengenai perempuan. Masyarakat Minangkabau menganut nilai yang mengatakan bahwa Minangkabau mempunyai kekhasan berupa sistem kekeluargaannya yang melalui jalur perempuan atau 
matrilineal (Malik,2016). Pada sistem kekerabatan matrilineal atau garis keturunan menurut garis ibu, kaum perempuan menempati posisi yang sangat penting dalam kehidupan bermasyarakat seperti menuntun anggota keluarga kepada yang baik, menyatukan anggota keluarga, serta harus berbudi dan berpendirian. Hal ini menunjukkan bahwa wanita dari etnis Minangkabau dituntut untuk mampu menjaga citra dirinya sebagai apapun posisisnya (Devi, 2014).

Nilai nilai yang tertanam diharapkan dapat menjadi panutan seseorang dalam bertingkah laku khususnya dalam budaya Minangkabau. Namun implikasi nilai-nilai tersebut dalam kehidupan sehari-hari semakin memudar. Hal ini dapat terlihat dari tingginya tingkat pelecehan terhadap wanita yang terjadi. Direktur women crisis center mengatakan bahwa banyak bentuk kasus kekerasan seksual yang terjadi khususnya pada wanita dan anak di Sumatera Barat masih tinggi (Sofriwandi, 2019). Pada tahun 2017 penelitian yang dilakukan oleh Perempuan Mahardika terhadap 773 buruh dari 45 pabrik menemukan bahwa 56,5\% responden mengalami pelecehan seksual ditempat kerja (Jumisih \& Asmawati, 2020). CATAHU juga mengatakan bahwa pada tahun 2019 terdapat setidaknya 200 kasus pelecehan terhadap perempuan yang dilakukan ditempat kerja termasuk di SUMBAR dan mengalami peningkatan kasus setiap tahunnya (CATAHU, 2019).

Sebuah hasil wawancara yang dilakukan dengan seorang subjek juga memberikan data yang serupa dengan beberapa penelitian tersebut. Subjek merupakan tenaga pendidik di Sumatera Barat. Ia mengaku pernah mendapatkan perlakuan yang tidak menyenangkan dari rekan kerjanya seperti dengan dicolek atau mendapatkan kata kata yang berunsur pelecehan seksual kepadanya. Hal ini menyebabkan ia merasa risih dan tidak nyaman selama bekerja karena berlawanan dengan nilai-nilai yang telah ditanamkan kepadanya bahwa perempuan harus bisa menjaga diri dan tidak boleh disentuh sembarang orang.

Kejadian serupa juga dialami oleh subjek S yang bekerja disebuah bank. Ia mengaku bahwa sering mendapat sentuhan fisik dan tatapan tidak menyenangkan. Ia memperoleh perlakuan ini dari teman kerja bahkan atasan. S mengaku merasa tidak nyaman mendapat perlakuan demikian. Namun karena tuntutan pekerjaan ia terpaksa menerima hal tersebut dan berusaha untuk bersikap terbiasa.

Pelecehan seksual didefinisikan sebagai perilaku seksual yang tidak disukai, permintaan perlakuan seksual, dan perilaku verbal atau fisik lainnya yang bersifat seksual" yang mengganggu pekerjaan atau kinerja kerja seseorang atau menciptakan lingkungan kerja yang bersifat ofensif (EEOC, 2011). Penelitian mengarah pada isolasi sosial sebagai suatu mekanisme yang menghubungkan pelecehan terhadap pembedaan jenis kelamin dan wewenang wanita, terutama dalam lingkungan kerja yang didominasi pria (McLaughlin,Uggen, \& Blackstone,2012). Pelecehan seksual yang terjadi memberikan dampak terhadap berbagai aspek termasuk aspek 
psikologis. Salah satu aspek yang dipengaruhi oleh korban yang mengalami pelecehan yaitu selfesteem.

Harga diri mencakup kemampuan akademik, kemampuan social ataupun harga diri kolektif yang bersumber dari etnis dan agama. Menurut Coopersmith self-esteem adalah evaluasi yang dibuat oleh individu dan biasanya berhubungan dengan penghargaan terhadap dirinya sendiri (Sandha dkk, 2012).

Sebuah hasil penelitian yang dilakukan oleh Birgisdóttir (2015) menunjukkan bahwa pelecehan seksual yang terjadi ditempat kerja menyebabkan korbannya memilki self-esteem yang rendah sehingga memberikan penilaian negative terhadap dirinya sendiri. Penelitian serupa yang dilakukan oleh Malik, Qureshi \& Atta (2014) untuk melihat dampak dari pelecehan seksual terhadap rendahnya self-esteem dan kepuasan kerja. Hasil menunjukkan bahwa pelecehan seksual merupakan salah satu predictor yang signifikan terhadap rendahnya selfesteem yang dimilki karyawan. Self-esteem yang rendah menyebabkan munculnya afeksi, perilaku serta pikiran negatif yang mempengaruhi proses pengambilan keputusan serta perasaan ketidakberdayaan dan rendahnya kepuasan kerja karyawan (Wheeler, 2010). Oleh karena itu penelitian ini bertujuan untuk melihat hubungan antara pelecehan seksual ditempat kerja terhadap karyawati di Sumatera Barat.

\section{Metode}

Desain penelitian ini menggunakan pendekatan penelitian kuantitatif. Cresswell (2008) mengatakan bahwa pendekatan kuantitatif adalah penelitian yang mengumpulkan data, dan menganalisis data menggunakan angka statistik. Penelitian ini menggunakan metode korelasi Product Moment untuk mengolah data. Metode ini dinggap paling sesuai untuk melihat sejauh mana efektifitas kontribusi pelecehan seksual yang dialami subjek terhadap self- esteem.

Populasi dan sampel

Populasi adalah wilayah generalisasi subjek dengan kuantitas dan karakteristik yang ditetapkan oleh peneliti untuk dipelajari dan kemudian ditarik kesimpulannya (Sugiyono,2011). Adapun populasi dalam penelitian ini adalah seluruh karyawan perempuan yang berasal dari Etnis Minangkabau di Sumatera Barat.

Sampel adalah sebagian dari jumlah karakteristik yang dimilki oleh populasi (Sugyono,2011). Adapun teknik yang digunakan untuk mengambil sampel adalah teknik purposive sampling yaitu teknik pengambilan sampel sumber data dengan beberpa pertimbangan tertentu. Adapun kriteri yang diberikan peneliti untuk subjek adalah: karyawan perempuan; keturunan asli etnis Minangkabau; Sudah bekerja di instansi tersebut minimal setahun.

Pengumpulan data 
Penelitian ini menggunakan skala sebagai sarana pengumpulan data. Azwar (2009) mengatakan bahwa skala adalah alat ukur yang berupa stimulus pertanyaan atau pernyataan yang mengungkap atribut yang akan diukur secara tidak langsung. Model skala yang digunakan dalam penelitian ini adalah Skala Likert yang terdiri dari empat alternative jawaban yaitu sangat sesuai (SS), sesuai (S), sangat tidak sesuai (STS) dan tidak sesuai (TS).

Adapun instrumen yang digunakan untuk memperoleh data pengukuran pelecehan seksual adalah skala SEQ-D0D Fitzgerald yang terdiri dari 12 aitem dengan $r=0,76$. Sedangkan untuk self-esteem menggunakan skala yang disusun berdasarkan indikator self-esteem Coopersmithyang terdiri dari 14 aitem dengan $r=0,54$. Untuk analisis data sendiri menggunakan bantuan dari aplikasi SPSS 20.

\section{Hasil Dan Pembahasan}

\section{Hasil}

Dari 35 responden yang mengisi skala peneleitian ini, 5 data responden ditolak karena tanggapan yang tidak lengkap sehingga hanya menyisakan 30 responden saja. Adapun rata-rata usia responden berkisar dari 20-46 tahun. Mereka bekerja dalam berbagai bidang profesi seperti tenaga pendidik, tenaga medis dan karyawan swasta.

Tabel 1: Kategorisasi skala Pelecehan seksual dan distribusi skor subjek

\begin{tabular}{|c|l|c|c|c|}
\hline Kategori & \multicolumn{1}{|c|}{ Norma } & Skor & \multicolumn{2}{|c|}{ Subjek } \\
\cline { 4 - 5 } & & & & \\
& & & & \\
\hline Tinggi & $\mathrm{M}+1 \mathrm{SD} \leq \mathrm{X}$ & $\leq 36$ & 2 & $0 \%$ \\
\hline Sedang & $\mathrm{M}-1 \mathrm{SD} \leq \mathrm{X}<\mathrm{M}+1 \mathrm{SD}$ & $24 \leq \mathrm{X}<36$ & 28 & $93 \%$ \\
\hline Rendah & $\mathrm{X}<\mathrm{M}-1 \mathrm{SD}$ & $\mathrm{X}<24$ & & \\
\hline
\end{tabular}

Berdasarkan skor kategorisasi tingkat pelecehan seksual tersebut dapat dilihat bahwa tidak ada responden yang mengalami pelecehan seksual yang berada pada skor tinggi atau $0 \%$. Adapun 30 dari responden terpilih hanya 2 responden atau sekitar $7 \%$ saja yang memiliki tingkat skor pelecehan seksual sedang. Sedangkan sisanya yaitu 28 responden atau $93 \%$ dari mereka memilki nilai skor pelecehan dibawah 24 sehingga berada pada kategori tingkat pelecehan seksual yang rendah.

Tabel 2: Kategorisasi skala self-esteem dan distribusi skor subjek 


\begin{tabular}{|c|l|c|c|c|}
\hline Kategori & \multicolumn{1}{|c|}{ Norma } & Skor & \multicolumn{2}{|c|}{ Subjek } \\
\cline { 4 - 5 } & & & $\mathrm{F}$ & $\%$ \\
\hline Tinggi & $\mathrm{M}+1 \mathrm{SD} \leq \mathrm{X}$ & $\leq 42$ & 27 & $90 \%$ \\
\hline Sedang & $\mathrm{M}-1 \mathrm{SD} \leq \mathrm{X}<\mathrm{M}+1 \mathrm{SD}$ & $28 \leq \mathrm{X}<42$ & 3 & $10 \%$ \\
\hline Rendah & $\mathrm{X}<\mathrm{M}-1 \mathrm{SD}$ & $\mathrm{X}<28$ & 0 & 0 \\
\hline
\end{tabular}

Adapun pada kategorisasi skor self-esteem menunjukkan bahwa 27 responden memiliki skor diatas 42 dan hanya 3 responden berada pada tingkat self-esteem yang rendah. Pada hasil uji normalitas data pelecehan seksual dan self-esteem Kologomorov Smirnov berada pada nilai sign 0.87 dengan nilai p 0.58 ( $p>0.05$ ). Oleh karena itu dapat disimpulkan bahwa data pelecehan seksual dan self-esteem berdistribusi normal.

Untuk uji homogenitas data pelecehan seksual dan self-esteem berada pada nilai sign 0.10 ( $p>0.05$ ). Maka dapat disimpulkan bahwa populasi dari kedua kelompok data adalah homogen.

Sedangkan hasil uji hipotesis menggunakan teknik analisis data korelasi Product Moment signifikansi berada pada nilai 0.43 ( $\mathrm{p}>0.05)$. Berdasarkan norma korelasi jika nilai sign $>0.05$ maka dapat disimpulkan bahwa tidak terdapat korelasi antara pelecehan seksual dengan self-esteem para responden.

\section{Pembahasan}

Hasil penelitian menunjukkan bahwa pelecehan seksual tidak berhubungan dengan tingkat self-esteem karyawati ditempat kerja. Pendapat ini bertolak belakang dengan kesimpulan penelitian Malik, Malik \& Atta (2017) yang mengatakan bahwa pelecehan seksual ditempat kerja berhubungan dan memberikan dampak negatif terhadap pekerjaan dan kepribadian seperti semangat kerja yang rendah, harga diri yang rendah, kinerja pekerjaan yang buruk. Pelecehan seksual yang merupakan topik sensitive di tempat kerja ternyata tidak mempengaruhi cara pandang individu mengenai harga dirinya.

Pada aspek pelecehan seksual tak langsung terdapat $67 \%$ subjek berada dikategori rendah dan 33\% subjek berada pada kategori pelecehan sedang. Adapun pada aspek pelecehan seksual langsung terdapat $50 \%$ berada pada kategori tinggi dan sisanya berada kategori rendah. Hal ini menunjukkan bahwasanya pelecehan langsung dan tak langsung yang dialami subjek hampir seimbang. Namun subjek cenderung lebih banyak mengalami pelecehan seksual secara langsung. Pelecehan seksual langsung dapat berupa tatapan mengintimidasi, catcalling, ucapan verbal dan siulan. Sebagaimana yang diketahui bahwa perilaku pelecehan seksual langsung 
terkadang tidak dikenali oleh para peleceh karena lebih mirip lelucon, komentar atau sapaan yang menyinggung (Prekel, 2001). Akan tetapi hal ini sangat mengganggu bagi korbannya namun hanya sedikit orang yang menyadari bahwa ia mengalami pelecehan seksual.

Pada aspek koersi seksual menunjukkan bahwasanya 90\% berada pada kategori rendah. Koersi seksual atau pemaksaan seksual didefinisikan sebagai pelecehan seksual yang berakibat langsung pada pekerjaan korban sebagian besar antara atasan dan bawahan seperti dengan mengancam akan memecat atau mengurangi gaji korban. Penanaman nilai-nilai budaya Minangkabau mengenai posisi kedudukan perempuan merupakan salah satu faktor yang dapat mempengaruhi pelaku untuk merasa segan atau malu ketika melakukan koersi seksual. Koersi seksual juga merupakan salah satu prediktor utama yang mempengaruhi pekerjaan karyawan selama di tempat kerja. Pendapat ini berbanding lurus dengan hasil penelitian, ketika koersi seksual yang merupakan salah satu aspek pelecehan seksual berhubungan dengan pekerjaan karyawan maka tingkat koersi seksual yang rendah tentu tidak akan mempengaruhi self-esteem karyawan selama bekerja (Ali, Zakaria, Zahari dkk, 2015).

Adapun aspek dengan jumlah subjek yang mengalami kategori terendah adalah perhatian yang tak diinginkan. Subjek dominan berada pada kategori rendah yang menunjukkan bahwa perhatian seksual yang tak diinginkan sangat jarang terjadi selama ditempat kerja. Namun perhatian yang tak diinginkan ini sangat sulit untuk dibedakan dengan perhatian biasa dan hanya sedikit korban yang menyadari bahwa perhatian yang tak diinginkan termasuk salah satu bentuk pelecehan. Sebuah hasil penelitian menemukan bahwa terdapat peningkatan resiko dalam bekerja terhadap karyawan yang mengalami perhatian yang tak diinginkan selama bekerja baik dari atasan, rekan kerja maupun pelanggan (Hogh, Conway, Cluasen, Madsen \& Burr, 2016). Rendahnya kesadaran terhadap perhatian ini menyebabkan subjek tetap memilki evaluasi positif tentang diri mereka, sehingga self-esteem subjek tetap tinggi.

Secara umum keseluruhan aspek self-esteem berada pada kategori tinggi. Hal ini memperkuat hasil penelitian yang melaporkan bahwa ternyata pelecehan seksual tidak berhubungan pada tinggi-rendahnya self-esteem subjek. Subjek yang memilki self-esteem pada kategori tinggi cenderung menunjukkan bahwa subjek tetap merasa berharga dan dapat menerima positif atau negative dirinya sebagai proses berkembang. Hal ini mengindikasikan bahwa self-esteem yang tinggi dapat membentuk kepribadian yang lebih positif, lebih mudah berinteraksi dengan orang lain dan lebih cepat bangkit dari kegagalan dengan mengatasi tekanan tekanan yang mereka alami khususnya tekanan ditempat kerja (Srisayekti \& Setiady, 2015). Dalam hal ini self-esteem tidak dipengaruhi oleh pelecehan seksual.

Salah satu aspek self-esteem dengan skor tinggi adalah kompetensi. Mereka yang memiliki skor kompetensi tinggi cenderung mampu menyelesaikan pekerjaan dan tugas mereka 
dengan baik serta memilki keinginan untuk berprestasi didunia kerjanya. Pendapat ini didukung oleh penelitian mengenai adanya hubungan efek self-esteem yang tinggi terhadap keadaan dan hasil kerja yang lebih baik bagi karyawan (Kuster, Orth \& Meier, 2013). Berdasarkan hasil penelitian tersebut dapat disimpulkan bahwa individu yang memilki selfesteem yang tinggi juga memiliki kompetensi diri yang tinggi terlepas dari ia mengalami pelecehan seksual ditempat kerja atau tidak.

Aspek lain dengan subjek yang cenderung berada pada kategori tinggi adalah kebajikan. Kebajikan erat kaitannya dengan penggunaan norma-norma serta etika moral yang di anut oleh para subjek. Salah satu penyebabnya adalah nilai-nilai moral yang sejak kecil ditanamkan kepada perempuan Minang mengenai posisinya sebagai seorang perempuan. Perempuan akan menjunjung tinggi moral dan etika mereka dalam melakukan berbagai kegiatan. Kebajikan didefinisikan sebagai kecenderungan manusia untuk merasakan, berpikir, dan bertindak dengan cara yang mengekspresikan keunggulan moral dan berkontribusi pada kebaikan bersama, diberlakukan sebagai kebajikan yang tidak nyata.

Sedangkan aspek terendah dari self-esteem adalah kekuatan. Aspek kekuatan berdampak terhadap cara individu untuk dapat mengatur dan mengkondisikan orang lain sehingga ia mendapatkan penghormatan dan pengakuan dari lingkungan sekitarnya. Ketika kekuatan individu berada pada kategori rendah maka ia akan kesulitan untuk melakukan pembelaan terhadap dirinya sendiri. Namun secara keseluruhan aspek self-esteem tetap berada pada kategori tinggi.

Penjelasan data menunjukkan bahwa pelecehan seksual yang terjadi pada karyawati etnis Minang di Sumatera Barat tidak berdampak terhadap self-esteem. Hal ini juga mengarahkan bahwasanya terdapat faktor faktor lain yang mungkin mempengaruhi self-esteem subjek seperti nilai-nilai yang mereka anut serta lingkungan yang mempengaruhi cara mereka berpikir.

\section{Kesimpulan Dan Saran}

\section{Kesimpulan}

Berdasarkan hasil penelitian dapat disimpulkan bahwa pelecehan seksual yang dialami oleh karyawati selama di tempat kerja di Sumatera Barat berada pada kategori rendah. Selfesteem karyawati yang bekerja di Sumatera Barat cenderung berada pada kategori tinggi. Pelecehan seksual di tempat kerja tidak berhubungan terhadap self-esteem karywati dari etnis Minangkabau di Sumatera Barat.

\section{Saran}

Adapun saran berdasarkan hasil pengkajian penelitian ini adalah bagi perempuan hendaknya lebih sadar terhadap pelecehan seksual yang sering mereka alami sehingga dapat membantu menekan rendahnya angka pelecehan seksual itu sendiri. Sedangkan bagi peneliti selanjutnya 
dapat menggunakan referensi pendukung lainnya untuk menambah wawasan bacaan khususnya mengenai pelecehan seksual dan self-esteem.

\section{Daftar Rujukan}

Ali, S. R. O., Zakaria, Z., Zahari, A. S. M., Said, N. S. M., \& Salleh, S. M. (2015). The effects of sexual harassment in workplace: Experience of employees in hospitality industry in Terengganu, Malaysia. Mediterranean Journal of Social Sciences, 6(4),689-695. doi: http://dx.doi.org/10.5901/mjss.2015.v6n4s2p689

Birgisdóttir, I. H. 2015. The effect of sexual abuse on self-esteem among adolescents: the impact of gender, parental support and type of perpetrator. Department of Psychology School of Business. 1-23 doi:http://hdl.handle.net/1946/2379

Clevelend, J. N\& Kress, M.E.1993. Sexsual harassement and perception of power: Underarticulated relationship. Journal of vocational Behavior. 49-67 doi: https://doi.org/10.1006/jvbe.1993.1004

Cresswel, J.,W. 2008. Educational research, planning, conducting, and evaluating quantitative and qualitative research. USA: Pearson Education

Devi, Silvua. 2014. Kedudukan dan peran bundo kanduang dalam system kekerabatan matrilineal di Minangkabau. Direktorat Jendral kebudayaan: Padang

EEOC. 2011. Sexsual Harassement. Retrieved from : $\underline{\text { https://www.eeoc.gov/sexual-harassment }}$

Fitzgerald,L.F.,Drasgow,F.,Hulin,C.L.,Gelfan,M.J., \& Magley,V.J. (1997). Antecedents and consequences of sexual harassment in organizations: A test of an integrated model. Journal of Applied Psychology, 82, 578-589. doi: http://dx.doi.org/10.1037/0021-9010.82.4.578

Handayani, A. 2013. Keseimbangan kerja keluarga pada perempuan bekerja: tinjauan teori border. Buletin Psikologi, 21(2), 90-101.

Helgeson, V. S. 2012. ThePsychology of Gender Fourth Edition. New York: Pearson

Hogh, A., Conway, P. M., Clausen, T., Madsen, I. E. H., \& Burr, H. (2016). Unwanted sexual attention at work and long-term sickness absence: a follow-up register-based study. $B M C$ public health, 16(1), 678.

Ismail, M.N., Chee, L. K \& Bee C. F. 2007. Factors influencing sexual harassment in the malaysian workplace. Asian Academy of Management Journal, 12(2), 15- 3. Retrieved from: https://www.ukessays.com/essays/sociology/factorinfluencing-sexual-harassment-inthe-malaysian-workplace-sociologyessay.php?vref

Jumisih., \& Asmawaty, A. C. 2020. Kekerasan seksual dan perempuan pekerja. Retrieved from: https://www.insideindonesia.org/kekerasan-seksual-dan-perempuan-pekerja

Kim, B. N., Park, S., \& Park, M. H. (2017). The relationship of sexual abuse with self-esteem, depression, and problematic internet use in Korean 
Kuster, F., Orth, U., \& Meier, L. L. (2013). High self-esteem prospectively predicts better work conditions and outcomes. Social Psychological and Personality Science, 4(6), 668-675. doi:https://doi.org/10.1177\%2F1948550613479806

Malik, N. I., malik, S., Qureshi, N., \& Atta, M. 2014. Sexual harassment as predictor of low self esteem and job satisfaction among in-training nurses. FWU Journal of Social Sciences, $8(2), 107-116$

Malik, R. 2016. Ikatan kekerabatan etnis minangkabau dalam melestarikan nilai budaya Minangkabau di perantauan sebagai wujud warga NKRI. Jurnal Analisa Sosiologi, 5(2) 1727 doi: https://doi.org/10.20961/jas.v5i2.18102

McGolgan, A. 2004. Report on Sexual Harassment in the Workplace in EU Member States, The Irish Presidency of the European Union in association with Farrell Grant Sparks Consulting. Dublin: Department of Justice, Equality and Law Reform.

McLaughlin, H., Uggen, C \& Blackstone, A. 2012. Sexual harassment, workplace authority, and the paradox of power. American Sociological Revie, 77(4), $625-647$ doi: https://doi.org/10.1177/0003122412451728

Perempuan, K. O. M. N. A. S. (2019). Catatan Tahunan Kekerasan terhadap Perempuan Tahun 2017. Jakarta: Publikasi Komnas Perempuan.

Pinna, A., Saunders, B., \& Gannon, T. A. 2017. An overview of the literature on sexsual harassement: Perpetrator, theory and treatments issues. Agression and Violent Behavior, 125- 138

Prekel, T. (2001). Sexual Harassment: Causes, Consequences and Cures. https://www.westerncape.gov.za/text/2004/4/sexual harassment Second upload.pdf

Sandha, T., Hartati, S., \& Fauziah, N. (2018). Hubungan antara self esteem dengan penyesuaian diri pada siswa tahun pertama SMA Krista Mitra Semarang. Empati,1(1), 47-82. Retrieved from: http://ejournal-s1.undip.ac.id/index.php/empati

Sofriwandy. 2019. Kekerasan Seksual Terjadi Setidaknya 35 Kali Setiap Hari. Retrieved from https://jarbatnews.com/kriminal/kekerasan-seksual-setidaknya-terjadi-35-kali-setiaphari/

Srisayekti, W., \& Setiady, D. A. (2015). Harga-diri (Self-esteem) Terancam dan perilaku menghindar. Jurnal Psikologi, 42(2), 141-156. doi: https://journal.ugm.ac.id/ipsi/article/viewFile/7169/5613

Sugiyono. 2009. Statistika untuk Penelitian. Jakarta: PT Raja Grafindo Persada

Trickett, P. K., Noll, J. G., \& Putnam, F. W. (2011). The impact of sexual abuse on female development: lessons from a multigenerational, longitudinal research study. Development and psychopathology, 23(2), 453-476. doi: https://doi.org/10.1017/S0954579411000174

Wheeler, S. B. (2010). Effects of self-esteem and academic performance on adolescent decisionmaking: an examination of early sexual intercourse and illegal substance use. Journal of Adolescent Health, 47(6), 582-590. doi: https://doi.org/10.1016/i.jadohealth.2010.04.009 